\title{
DISTRIBUTION OF PRAIRIE PASQUEFLOWER IN SASKATCHEWAN
}

\section{Vladimir Kricsfalusy}

School of Environment and Sustainability

University of Saskatchewan

117 Science Place

Saskatoon, SK S7N 5 C8

vladimir.k@usask.ca

\section{Introduction}

Identifying and mapping new

locations of sensitive species is

an essential component of the

biodiversity conservation process.

Recently, we have developed a new approach for mapping distribution of vascular plant species in

Saskatchewan, which contributes to biodiversity assessment at different spatial and temporal scales (Kricsfalusy et al. 2015). ${ }^{1}$ The suggested approach demonstrates on the model species - prairie pasqueflower (Pulsatilla nuttalliana (de Candolle) Berchtold ex J. Presl, syn. Anemone patens L. subsp. multifida (Pritzel) Hultén) — how to combine traditional research records (herbarium collections and field surveys) and citizen science (phenological observations) with modern technologies (GIS, GPS, and online databases) to map plant species distribution and analyze their habitats affinities ${ }^{1}$.

Precise data about distribution of prairie pasqueflower, which were lacking for many areas in Saskatchewan, was a vital part of the above-mentioned approach. Due to the size limit for a journal article, we were not able to publish detail distribution data, i.e. list of locations of prairie pasqueflower

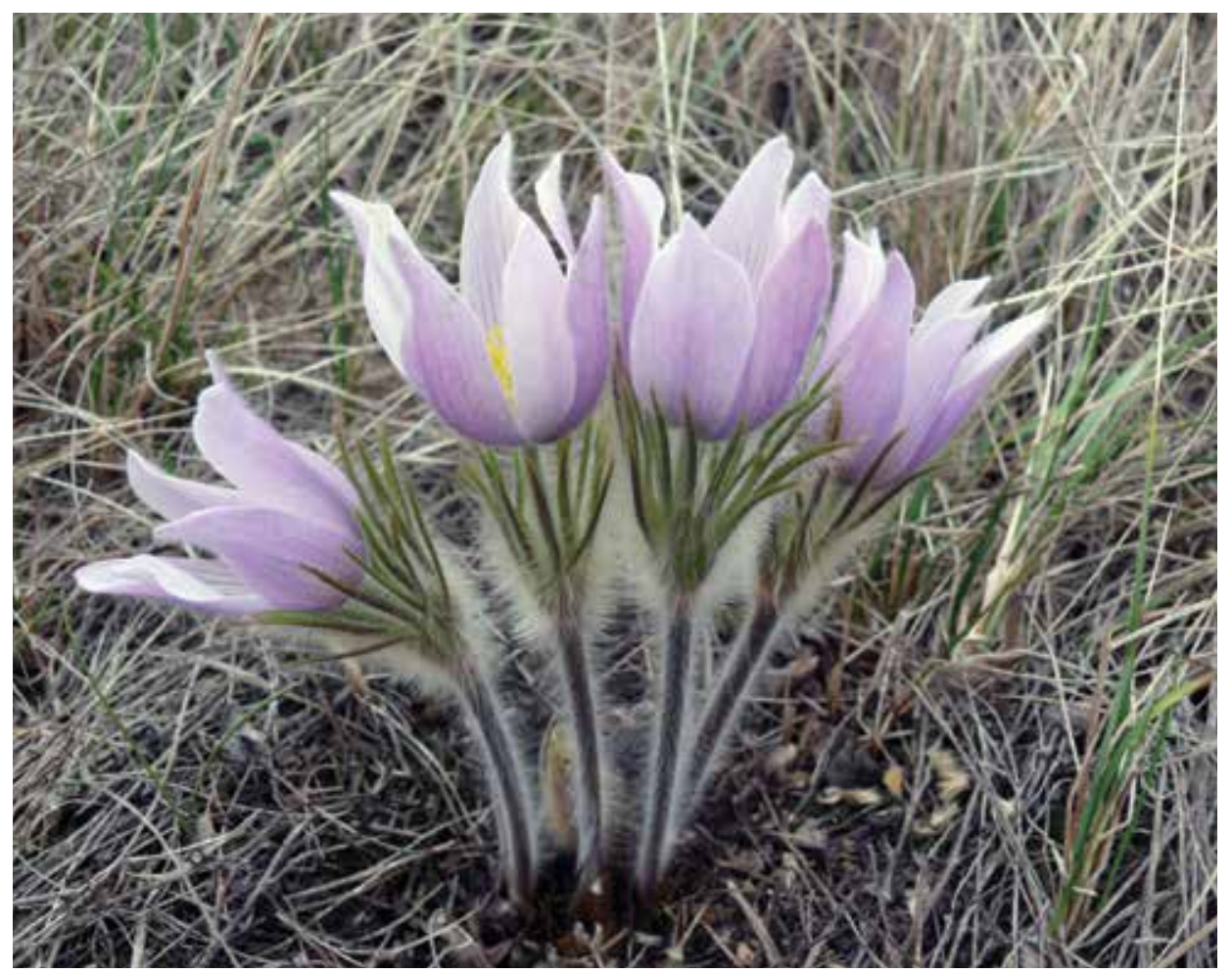

FIGURE 1. Prairie pasqueflower in full bloom in Northeast Swale, Saskatoon. Photo credit: V. Kricsfalusy

in Saskatchewan, in our previous paper. ${ }^{1}$ Therefore, in this paper we aim to fill the information gap on distribution of prairie pasqueflower by providing existing but previously unpublished data (herbarium records, phenological observations and field occurrences). Overall, these baseline data can be used to establish effective population monitoring which will provide conservationists with important insights into how prairie pasqueflower may respond to the increasing anthropogenic impact.

\section{Methods}

Distribution records of prairie pasqueflower (Figure 1) were obtained from 1) herbarium specimens collected in the period from 1920 to 2000, 2) phenological observations reported by citizen scientists (2001-2010), and 3) our field surveys (2011-2013, with some locations registered in 2014 2018). For detailed description of the methods used for collecting data and quality assurance processes, analyzing and mapping distribution of prairie pasqueflower, please see our previous paper. ${ }^{1}$ Below we provide only key methodological points.

The primary sources of herbarium data were specimens of prairie pasqueflower from the collections in the W.P. Fraser Herbarium at the University of Saskatchewan (SASK) ${ }^{2}$ and the G.F. Ledingham Herbarium at the University of Regina (USAS). ${ }^{3}$ Based on those data, 168 locations were selected for distribution analysis. In addition, 9 records were compiled from specimens obtained from three other Canadian herbaria. ${ }^{1}$ Phenological 
observations on prairie pasqueflower recorded by citizen scientists are available in the SK PlantWatch ${ }^{4}$ database from which through quality assurance processes 23 observation records were used in our study. The georeferenced species locations collected during our field surveys generated the largest source of data. A total of 248 point occurrences of prairie pasqueflower were selected from these georeferenced data for distribution analysis.

Maps depicting the distribution of prairie pasqueflower were prepared using the GIS program ArcMap 10.5. To develop the species distribution map we used a new approach for mapping flora of Saskatchewan. ${ }^{1}$ The grid template was divided into mapping cells of $50 \mathrm{~km} \times 50 \mathrm{~km}$. For mapping prairie pasqueflower in Saskatoon we used an approach previously applied in Toronto, Ontario. ${ }^{5}$ In this case, the grid template was divided into mapping cells of $2 \mathrm{~km} \times 2 \mathrm{~km}$.

\section{Results and Discussion}

Analysis of the distribution of prairie pasqueflower in Saskatchewan allowed us to identify spatial patterns of species range. ${ }^{1}$ The most important of them is the gradual decrease in the number of species locations within the province as we move from south to north and from west to east. The center of the prairie pasqueflower latitudinal range in Saskatchewan was found to roughly overlap with the northern and southern boundaries of the Prairie ecozone (Figure 2). Lists of the 448 locations of prairie pasqueflower - herbarium records (168),

phenological observations (23), and author's field surveys (248) - which were not published in our previous paper ${ }^{1}$ are presented in Tables 1-3.

In addition to these findings, collected information allows us to shed light on some temporal and spatial patterns of the distribution of prairie pasqueflower which wasn't elaborated in our previous paper. ${ }^{1}$ Below we describe historical collections of prairie pasqueflower in Saskatchewan (temporal patterns at regional scale) and features of species distribution in Saskatoon (spatial patterns at local scale).

\section{Historical collections in Saskatchewan}

It turns out that specimens of prairie pasqueflower deposited in the W.P. Fraser Herbarium at the University of Saskatchewan (SASK) provide a unique opportunity not only for the species distribution analysis but also to look at history of botanical explorations in the

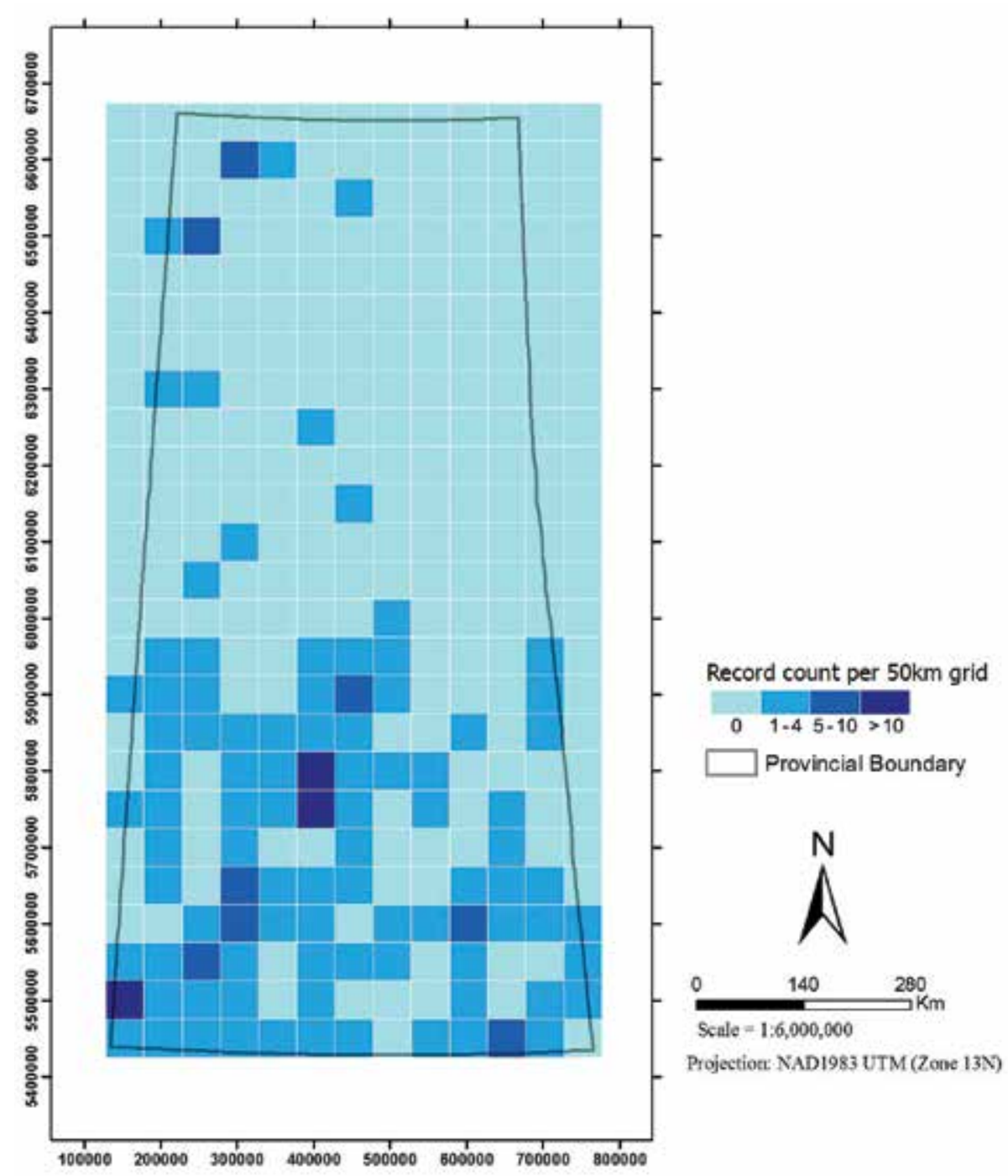

province. According to our analysis, a total of 75 collectors deposited 137 specimens of the prairie pasqueflower in the SASK herbarium from 1920 to 2000 (Figure 3). Given the amount and character of the available information, we divided these distribution data into 9 decades and after that grouped them into three periods.

The first period, from 1920 to 1950, is characterized by scarcity of information. The distribution data for the initial two decades (1920-1940) include only 14 specimens of prairie pasqueflower deposited by 10 collectors. This could be largely due to the small number of collectors, concentration of their activity in more approachable areas of the province

FIGURE 2. A distribution map of prairie pasqueflower in Saskatchewan (from Kricsfalusy et al. 20151). 


\section{TABLE 1. List of herbarium specimens $(n=168)$ of prairie pasqueflower collected in Saskatchewan (SASK and USAS, 1920-2000).}

\section{A. LIST OF REPRESENTATIVE SPECIMENS ( $N=134$ ) IN THE W.P. FRASER HERBARIUM AT THE UNIVERSITY OF SASKATCHEWAN (SASK)}

Moose Mountain Creek Valley, 31 May 1987, V.L. Harms (SASK 92761); Saskatoon, Sutherland Beach, 31 May 1997, B. Wlad (SASK 145197); SW end of Cluff Lake, 15 June 1977, V.L. Harms (SASK 65678); Uranium City area, 2 km W of Uranium City mine operations, 23 August 1981, V.L. Harms (SASK 75399); E of Stewart Valley, near Swift Current, 18 April 1969, J. Looman (SASK 107921); W of Saskatchewan Landing, 18 April 1969, J. Looman (SASK 107922); Wiseton, 22 mi S, L.S.D 4 in S32 T23 R12 W3, 27 May 1978, J.H. Hudson (SASK 68070); Gravelbourg, Wood River area, NE 24 T12 R5 W3, 18 June 1981, A. Schewe (SASK 73380); Skinner Marsh, SW S23 T19 R12 W3, 8 May 1975, V.J. Leiffers (SASK 122444); Cochin, 17 July 1963, J. Looman (SASK 107915); S of Rush Lake, Swift Current, 24 May 1963, J. Looman (SASK 107914); mi 51, Hwy 155, 11 mi. S of Beauval Forks, Beaver River Valley, 12 July 1972, V.L. Harms (SASK 46450); Stony Rapids, 12 August 1960, J.S. Maini (SASK 11329); 8 mi. NW of Duck Lake, 20 May 1955, L.W. Gellata (SASK 11380); Saskatoon, ?, O. C. Furniss (SASK 144311); Cypress Hills, 10 June 1953, K.F. Best (SASK 121042); Rock Glen, 4 July 1963, J. Looman (SASK 107916); NE end of Cluff Lake, above AMOK exploration site, 13 July 1977, V.L. Harms (SASK 65301); Waterhen River Crossing, near Meadow Lake, 17 May 1966, J. Looman (SASK 107917); 8 mi. E of Saskatoon, 27 September 1954, G.W. Selleck \& R.T. Coupland (SASK 11378); Masefield PFRA Community Pasture, 22 April 1969, J. Looman (SASK 107920); Saskatoon, 30 May 1933, W.P. Fraser (SASK 11375); SE end of Cluff Lake, 12 June 1972, V.L. Harms (SASK ?); Katepwa Lake, 6 May 1953, R.C. Russell (SASK 82909); Saskatoon, Sutherland, 20 April 1958, D. Riley (SASK 82910); Saskatoon, 11 May 1927, H. Cameron (SASK 11392); Swift Current, 5 May 1936, J.L. Bolton (SASK 108010); Midale, ? May 1940, G.C. ? (SASK 43719 ); Cadillac R. A., Sec8 T7 R13 W3, 28 April 1947, A.C. Budd (SASK 108017); Cypress Hills, 16 August 1944, A.C. Budd (SASK 108014); Besnard Lake, ca 1-2 km N of Narrows Channel Crossing, 33 km off Besnard Lake Road, 25 June 1992, V.L. Harms (SASK 132861); Besnard Lake, T73 R1 W3, 23 June 1992, V.L. Harms (SASK 132860); Swift Current, 5 May 1937, J.L. Bolton (SASK 11386); Saskatoon, 15 May 1938, W.P. Fraser (SASK 11333); Cranberry Flats recreation site, $3.5 \mathrm{mi}(5.5 \mathrm{~km})$ S of Saskatoon. Along E shore of South Saskatchewan River, LSD 2,5,6,7 \& 8 Sec30 T35 R6 W3, 18 June 1992, M. Lineman (SASK 163234); Saskatoon, E shore of South Saskatchewan River, NW of Sutherland subdivision, behind Regional Psychiatric Centre, LSD 7 Sec10 T37 R5 W3, 8 July 1993, M. Lineman (SASK 169299); Saskatoon, Silverwood, Sec14 T37 R5 W3, 11 August 1994, M. Lineman (SASK 163788); Saskatoon, Silverwood, Sec14 T37 R5 W3, 25 May 1994, M. Lineman (SASK 163598); Moose Mountain Creek Valley, 12 August 1987, V.L. Harms (SASK 129402); Cypress Hills, 13 May 1952, K.F. Best \& J. White (SASK 121041); Swift Current, Alexander farm, NE S20 T15 R13 W3, 12 May 1952, A.C. Best \& K.F. Best (SASK 121040); Saskatoon, 29 May 1933, R.J. Ledingham (SASK 82907); Saskatoon, 6 September 1933, R.C. Russell \& R.J. Ledingham (SASK 82906); Bonefield, NE shore of Lake Athabasca, 19 May 1973, L. \& L. Muller-Wille (SASK 54469); Saskatoon, 11 May 1949, G.E. Fraser (SASK 11379); Lizard Lake, 21 May 1961, R.C. Russell (SASK 82903); Saskatoon, 14 April 1938, ? (SASK 11394); Cypress Hills Provincial Park, 7 June 1953, S. Zilke (SASK 11385); Prince Albert, 3 May 1940, O.C. Furniss (SASK 144238); Rolling prairie, NE of Saskatoon, 13 May 1960, C. Robert (SASK 26420); Saskatoon, 27 April 1923, ? Gios (SASK 82904); Saskatoon, 3 June 1927, B.G.S. (SASK 82905); Chipewyan, 20 May 1981, R. Marles (SASK 78520); NE shore of Cluff Lake, 7 June 1993, J. Ternier (SASK 169784); 7 mi. N of Birmingham, 10 May 1992, W. Schatz (SASK 134977); N shore of Brightsand Lake, ca 22 km E of St. Walburg, S1/2 Sec10 T54 R20 W3, 11 July 1999, V.L. Harms (SASK 147229); 4 mi. E of Carlyle, NW 1/4 Sec2 T8 R2 W2, ? 1998, D. Silcox (SASK 145264); SE of Tompkins, near Swift Current, 21 April 1969, J. Looman (SASK 107899); Souris River Valley, Estevan area, ca 1.5 km S just N of Woodland Regional Park, SW1/4 Sec14 T2 R8 W2, 26 May 1986, V.L. Harms, D.F. Hooper \& L. Baker (SASK 129857); W of Fort Pitt, 15 May 1973, J. Looman (SASK 107873); Frenchman River badlands, 27 May 1969, J. Looman (SASK 107905); Pinto Butte, 4 May 1970, J. Looman (SASK 107878); 8 mi. E of Swift Current, 18 April 1969, J. Looman (SASK 107903); Hansen Lake Road, Narrow Hills Provincial Park, Lower Fishing Lake, 24 June 1964, G.W. Argus (SASK 25500); Tompkins, 13 June 1985, J. M. Perron (SASK 120007); Uranium City area, Lodge Bay, 8 km E of Lorado area, ca 30.5 km S, 23 August 1981, V.L. Harms (SASK 75348); Souris River Valley, Elcott, ca 2 mi. N in local campgrounds area, NW 1/4 Sec25 T1 R3 W2, 28 May 1986, V.L. Harms (SASK 129366); Saskatoon, Silverspring Prairie, NW Sec12 T37 R5 W3, 10 July 1990, V.L. Harms (SASK 132309); Souris River Valley, N of Roche Percee, NE 1/4 Sec36 T1 R6 W2, 26 June 1986, V.L. Harms (SASK 129364); Moose Jaw, Thunder Creek, 19 May $1985, B$. Cooper (SASK 94775); Wellington P.F.R.A. Community Pasture, near Tyvan, 9 May 1985, B. Kishchuk (SASK 90451 ); 52 km E of Saskatoon along Hgw 5, NW 1/4 Sec33 T36 R28 W2, 22 June 1986, J. Neufeld (SASK 140505); N of Saskatoon, Northern Chemical Terraces on NW shore of South Saskatchewan River, NW 1/4 LSD 2 Sec26 T37 R5 W3, 31 May 1993, M. Lineman (SASK 169686); ca. 1.5 mi. SE of Dundurn, Sec35 T 32 R4 W3, 16 April 1992, J. Neudorf (SASK 134748); Western half of Fort-a-la-Corne area, near confluence of North and South Saskatchewan River, Sec13 T49 R22 W2, 10 July 1980, B. Godwin \& L. Baschak (SASK 134396); Elbow, LLD NW S13 T 25 R5 W3, 21 May 1992, B. Wait (SASK 136141); The Pines, NE S34 T48 R21 W2, 25 May 1995, B. Wait (SASK 136140); Besnard Lake, T73 R1 W3, 17 May 1995, M.M. Hart (SASK 137584); 9 mi. W of Birsay and 1.75 mi. N, NW 1/4 Sec9 T52 R9 W3, 30 May 1996, B. Robson (SASK 137980); Prince Albert National Park, SW 1/4 Sec5 T57 R1 W3, 29 June 1996, V.L. Harms (SASK 139720); Sandy Prairie N of Strawberry Lake, 12 mi. S of Indian Head, 13 May 1965, G.J. Jones, L. Roney \& G. Allen (SASK 32295); Saskatchewan Landing, Swift Current, 13 May 1969, J. Looman (SASK 107906); Uranium City area, S side of Hanson Bay at SW end of Beaverlodge Lake, ca $1.5 \mathrm{~km} \mathrm{~S}$, SW of Lorado Wharf, 22 August 1981, V.L. Harms (SASK 75347); N side of Lake Athabasca near Uranium City, ca 1.5 km S, 5 July 1979, V.L. Harms (SASK 70252); Prominent dolomite outcrop ridges of carswell formations, about 8 km W of Cluff Lake, 18 July 1977, V.L. Harms (SASK 65337); Souris River Valley, ca 5 mi. SE of Estevan, NE $1 / 4$ Sec34 T1 R7 W2, 24 July 1987, V.L. \& R.M. Harms (SASK 129648); Souris River, ca 1/4 mi. N of Roche Percee campground, NE 1/4 Sec33 T1 R6 W2, 20 May 1988, V.L. Harms (SASK 129867); 5 km NW of Bredenbury along Yellowhead Hwy, 18 May 1982, P. Burton (SASK 134031); N of Lumsden, 4 May 1985, A.M. Tuchscherer (SASK 79537); S of Maidstone, 14 May 1973, J. Looman (SASK 107890); Carruthers, 3 May 1973, J. Looman (SASK 107872); 0.5 km S of Saskatoon, on Clarence Avenue at junction with freeway, 20 May 1986, P.A. Ryan (SASK 898594); Cranberry Flats, 12 May 1985, W. Chypkowski (SASK 81435); Otosquen, mi. 27, N of Melfort, 14 May 1970, J. Looman (SASK 107887); Moose Jaw-Watrous quad, 28 April 1969, N.A. Skoglund (SASK 41756); Duff, near Yorkton, 13 May 1970, J. Looman (SASK 107896); N of Whitewood, Qu'Appelle River, 15 May 
1963, J. Looman (SASK 107912); E of Matador, 22 May 1969, J. Looman (SASK 107904); Monet C.P., Elrose, 21 May 1963, J. Looman (SASK 107913); 0.25 mi. N of Mozart, SW of Wadena, 15 km E of Wynyard, T32 R15 W2, 2 May 1982, S. Weldon (SASK 134120); S of Tompkins, 23 April 1969, J. Looman (SASK 107902); N of Webb, 17 April 1969, J. Looman (SASK 107901); 4 mi. N of Cando, 10 May 1971, J. Looman (SASK 107987); W of Muddy Lake, 14 May 1973, J. Looman (SASK 107898); Rolling prairie NE of Saskatoon, Sec12 T37 R4 W3, 19 April 1960, R. Connel (SASK 26421); 3 mi. SE of Coderre, 28 May 1986, D.G. Huel (SASK 81286); Clearwater River, near Methy portage, in an open S sloping area with a thin Jack pine canopy, 13 June 1979, R. A. Wright (SASK 72376); Beaver Creek, ca 9 mi. S of Saskatoon, 4 June 1978, A. Doug (SASK 70969); The Pinehouse, Key Lake Road, ca 23 km E of Orphan Lake, on Haultian River, 24 August 1979, B. Godwin Z. Abouguendia (SASK 72011); N side of Lake Athabasca, Langley Bay, ca 2.5 km. N of Gunnar towards S end of Crackingstone Peninsula, 8 August 1981, V.L. Harms \& P.L. Sky (SASK 75346); Watrous, 20 May 1938, J. Campbell (SASK 108012); Saskatoon, 30 May 1936, W.P. Frazer (SASK 108011); Cranberry Flats, 12 May 1985, E. Yaworski (SASK 81504); Saskatoon, 2 June 1920, W.P. Fraser (SASK ?); Cadillac R.A., Sec8 T7 R13 W3, 2 May 1946, A. C. Budd (SASK 108015); Souris River Valley, just N of Roche Percee campground, $3.5 \mathrm{~km}$ east and $1.5 \mathrm{~km}$ N of Roche Percee, NE 1/4 Sec33 T1 R6 W2, 26 May 1986, V.L. Harms, D.F. Hooper \& L. Baker (SASK 129365); 7 km W of Truax, 29 May 1975, J. Looman (SASK 107874); Along Hwy 5, 2.5 mi. E of Quill Lake, 3 June 1959, C.H. Hood (SASK 11393); 12 mi. S of Saskatoon, 17 May 1961, R. Newsome \& G. Hulett (SASK 11387); Moose Jaw - Watrous quad, T20 R13 W3, 16 July 1969, N.A. Skoglund (SASK 41929); Upper Rousay Lake, 28 May 1973, A. Schmidt (SASK 123367); Near Court, Kindersely, 12 May 1973, J. Looman (SASK 107875); N of Murrayadale, 3 June 1970, J. Looman (SASK 107888); Hearts Hill Community Pasture, 11 May 1972, J. Looman (SASK 107889); S of Wiseton, 8 May 1970, J. Looman (SASK 107882); 5 km NW of Verlo, S11 R16 T20 W3, 7 May 1970, J. Looman (SASK 107883); N of Rosetown, Eagle Creek, 8 May 1970, J. Looman (SASK 107884); Near Lady Lake, 15 May 1970, J. Looman (SASK 107885); E of Glidden, 27 May 1970, J. Looman (SASK 107886); S of Dellard, Frenchman River, 15 May 1970, J. Looman (SASK 107879); East of Mawer, 6 May 1970, J. Looman (SASK 107880); SE of Roadene, S22 R17 T20 W3, 7 May 1970, J. Looman (SASK 107881); Wooded draws of Matador Research Station, NW 1/4 Sec14 T20 R13 W3, 18 June 1991, D. Lawrence (SASK 133834); Wooded draws of Matador Research Station, NW 1/4 Sec14 T20 R13 W4, 3 June 1992, D. Lawrence (SASK 133772); Lily Plains natural prairie, ca $1 \mathrm{mi}$. W of Lily Plains (ca 13-14 km W of Prince Albert), ca 1.5 mi. S of North Saskatchewan River, NE $1 / 4$ Sec29 T48 R1 W3, 7 July 1994, V.L. \& R.M. Harms (SASK 133681); Coteaue region, SE1/4 Sec35 T23 R12 W3, about 8 mi. N \& 8.5 mi. W of Beechy \& 19 mi. W and 1 mi. N of Lucky Lake, 9 June 1996, R. Salmon \& B. Corinne (SASK 141943); E of Carlyle, NW 1/4 Sec2 T8 R2 W2, ? May 1995, D. Silcox (SASK 142755); Biggar, 9 July 1996, V. Leuschen (SASK 140382); E Ridhe Road at Armit River, 5 km S and 5.5 km E of Armit (1-1.5 km W of Manitoba border, SW 1/4 Sec13 T44 R29 W2, 28 June 1983, V.L. Harms, D.F. Hooper \& L. Baker (SASK 140906); Saskatoon, Silverspring prairie, WC to NW Sec12 T 37 R5 W3, 21 April 1991, V.L. Harms (SASK 140756); Close to S Shore of Candle Lake, 8 July 1962, J.M.A. Swan (SASK 32595); The Pinehouse - Key Lake Road, ca 23 km E of Orphan Lake, on Haultian River, 28 July 1979, B. Godwin \& Z. Abouguendia (SASK 68262); The Biddulph Half Section Research Area, ca 21 km S of Saskatoon along Road 219, just N of White Cap Indian Reserve, SE 1/4 LSD 1 Sec12 T34 R6 W3, 3 June 1986, B. Pylypec (SASK 97862); The Biddulph Half Section Research Area, ca 21 km S of Saskatoon along Road 219, just N of White Cap Indian Reserve, SE $1 / 4$ LSD 1 Sec12 T34 R6 W, 7 May 1987, B. Pylypec (SASK 97953); The Kernen Prairie, ca 2.5 km E of Sutherland subdivision, E Saskatoon, SE $1 / 4$ of Sec16 T37 R4 W3, 17 May 1985, B. Pylypec (SASK 97074); The Pinehouse, ca 23 km E of Orphan Lake, on Haultain River, 24 August 1979, B. Godwin \& Z. Abouguendia (SASK 68282); Near NE end of Cluff Lake, AMOK exploration camp, 19 July 1977, V.L. Harms (SASK 65303); N of Antelope, 21 July 1969, J. Looman (SASK 107900); NE of Coronach, Sec1 T3 R26 W2, 5 July 1980, Z. Abouguendia (SASK 92106); North Battleford, 17 May 1985, P. Grillz (SASK 81211); $\mathrm{N}$ base of Pasquia Hills at S edge of Carrot River Valley, Near Rice River campsite, 4 km E of Rice River Crossing on Hwy 55, Sec34 T52 R3 W2, 18 July 1984, D.F. Hooper \& L. Baker (SASK 92713); SE of Little Fishing Lake, NW Sec11 T56 R24 W3, 24 July 1977, J. Haraldson \& T. Rock (SASK 123368).

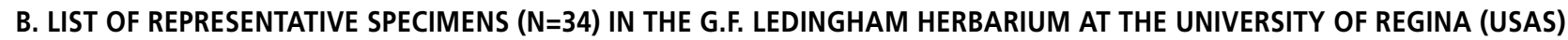

White City, 2 miles N and Pilot Butte natural area N of gravel pits, 16 May 1985, G.F. Ledingham (USAS 7982); NW 11, 37, 9ws, Asquith study area, 22 May 1970, G.W. Pepper (USAS 7929); West Block of Cypress Hills, N of field station, NE S20 T7 R29 W3, 21 May 1984, G.F. Ledingham (USAS 7930); Sommet du Coteau Boise au sud de Tompkins, 13 June 1958, B. Boivin \& J.M. Perron (USAS 7931); Wiseton, 22 miles S, L.S.D. 4 S33 T23 R12 W3, 27 May 1978, H. Hudson (USAS 7932); Dundurn, 27 May 1975, E.W. Sullivan (USAS 7933); Bethesda Church, 4 miles W, Dummer 9 miles N, Milestone 15 miles W, 28 April 1980, G.F. Ledingham (USAS 7934); Belanger Creek, east end of Cypress Lake, N bank, May 09 1957, G. F. Ledingham (USAS 7936); Sissor Creek area in Qu' Appelle Valley, 10 miles of Rocanville, 21 May 1966, G.F. Ledingham (USAS 7937); Superme, Twp 2, Rg 26, Sec 35, 01 August 1969, G F. Ledingham (USAS 7938); Crooked Lake in Qu'Appelle Valley, 05 May 1975, G. Anweiler (USAS 7939); Prince Albert, 24 April 1955, M.A. Welsh (USAS 7941); Prince Albert, 02 May 1955, M.A. Welsh (USAS 7942); Prince Albert National Park, 23 May 1955, M.A. Welsh (USAS 7942); Regina, 3 miles E, 29 April 1949, B. Rawlinson \& G.F. Ledingham (USAS 7943); Cypress Hills PP, road to Ranger station, 22 May 1960, D.R. Wade \& D.E. Wade , 22 May 1960 (USAS 7944); Regina, 6 miles NW, Hungry Hollow, D.R. Wade \& D.E. Wade (USAS 7945); Estevan, SE \& Sec7 T2 R7 W2, 09 July 1971, M.E. Jonescu (USAS 7946); Estevan, S31 T1 R8 W2, 31 July 1973, M.E. Jonescu (USAS 7947); Indian Head, 9 miles 5, 19 May 1949, G.F. Ledingham (USAS 7949); Cactus Hills, 8 miles SW of Briercrest, 12 miles W of Hearne, NW S19 T13 R25 W2, 28 July 1987, G.F. Ledingham (USAS 7950); Missouri Coteau, Dirt Hills, 6 miles SE of Spring Valley, 25 April 1986, G.F. Ledingham (USAS 7951); Strawberry Lakes N, 12 miles S of Indian Head, 13 May 1965, G.J. Jones \& L. Roney \& G. Allen , (USAS 7952); Cactus Hills, Dry Lake N, Strawberry Lakes 12 miles S of Indian Head, N 1/2 S22 T16 R13 W2, 24 May 1979, G.F. Ledingham (USAS 7953); Missouri Coteau, Dirt Hills, 6 miles S and 5 miles W of Avonlea, SW S11 T12 R24 W2, G.F. Ledingham (USAS 7954); Melaval 2 miles N, 22 April 1969, G. Walker\& N. Walker (USAS 21062); Melaval 2 miles N, 22 April 1969, G. Walker\& N. Walker (USAS 21063); Grasslands NP, E side of East Block, 7 miles W of Killdeer \& NE S7 T2 R4 W3, 14 May 1990, G.F. Ledingham (USAS 31911); Val Marie, West Block; 49 N, 107 W, 05 May 1970, B. de Vries (USAS34034); Pheasant Creek coulee, Katepwa, Qu'Appelle Valley, E of Fort Qu'Appelle, 14 May 1960, B. de Vries (USAS 34035); Fort Qu'Appelle, 02 June 1959, B. de Vries (USAS 34036); Swift Current, 12 May 1952, A.C. Budd (USAS 34037); Maryfield, N, Pipestone Valley, 07 May 1967, B. de Vries (USAS 34038); Osage, 16 miles E, N end of Goosberry Lake, 21 May 03, G.F. Ledingham \& H. Morrison (USAS 47122). 
and around large towns with research centers (e.g., more than half of all specimens were collected in Saskatoon and its vicinity) and possible economic impact of the Great Depression. During 19411950, only two collectors deposited four specimens as this time period coincides with World War II.

The second period, from 1951 to 2000 , is characterized by a significant increase in the number of collectors and deposited specimens of prairie pasqueflower. Over the initial decade (1951-1960) of this period number of collectors increased to 13, although adequate change in number of herbarium specimens is not observed (13). The highest number of specimens (36) was deposited in the next decade (1961-1970), most likely due to intensification of agriculture, forestry practices and industrial development in the province which led to an increased interest in floristic surveys. After that, collection efforts plateau for the next decades (1981-2000) with large numbers of collectors (18).

The third period, from 2001 until 2018, is characterized by a sharp decline in both collectors and specimen collections probably due to a decrease in research funding and general interest in botany. There are no specimens of prairie pasqueflower deposited during this period in the SASK herbarium. However, the additional data on distribution of prairie pasqueflower in Saskatchewan were obtained from the phenological observations deposited in the SK PlantWatch database (2001-2010: 23 locations) and our field surveys (2011-2018: 248 locations). In terms of mapped grid cells $50 \mathrm{~km} \times 50 \mathrm{~km}$, these records account for 17 new mapping units ( $17.3 \%$ of total) of prairie pasqueflower in Saskatchewan
(Figure 2). It should be noted that this map represents the record count (herbarium vouchers, phenological observations, and field surveys) and as such is a function of collecting bias. It may not be necessarily representative of true density of prairie pasqueflower in any given area.

\section{Spatial distribution in Saskatoon}

To determine how well herbarium and phenological data reflect actual distribution of prairie pasqueflower in the best sampled part of the species range, i.e. city of Saskatoon and its vicinity, we conducted intense field surveys in this area during a few vegetation seasons. The design of surveys aimed to confirm sites that have already been visited by previous researchers and from which herbarium and literature records are available, as well as to investigate occurrence of prairie pasqueflower in potentially suitable habitats.

We hypothesized that remnant prairie habitats scattered within the urban landscape in Saskatoon may provide suitable niches for prairie

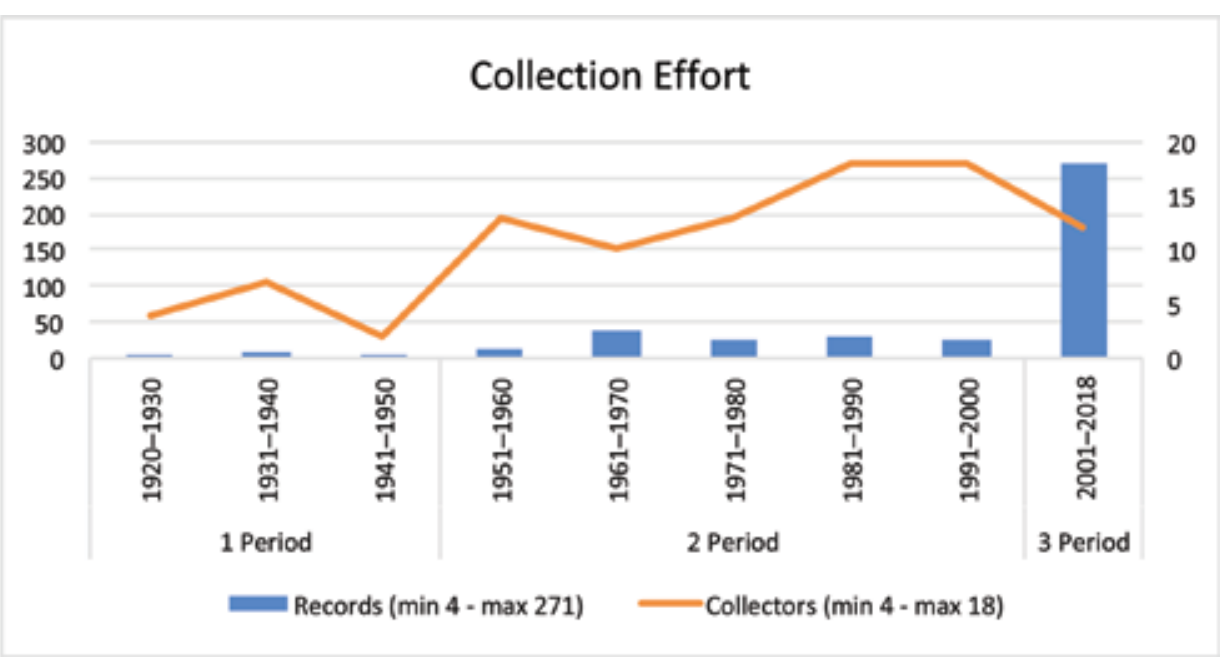

FIGURE 3. Historical collections of prairie pasqueflower in Saskatchewan. Data derived from the SASK herbarium (1920-2000); SK PlantWatch database (2001-2010) and author's field surveys (2011-2018).

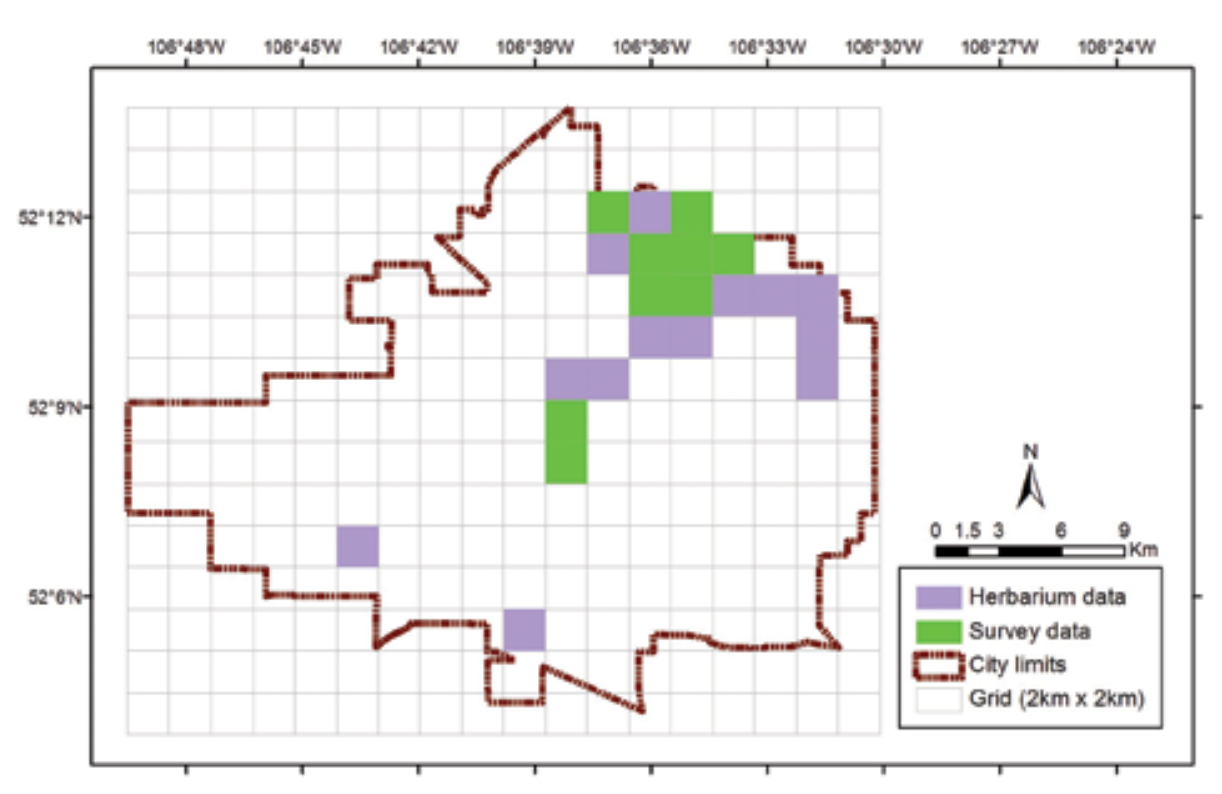

FIGURE 4. A distribution map of prairie pasqueflower in Saskatoon.(from Kricsfalusy et al. 20151). Note: information from primary sources about dates and names of observers is not available in the database. 
pasqueflower. Our study identified that the historical data on distribution of prairie pasqueflower in Saskatoon account for 13 grids cells ( $2 \mathrm{~km} \times 2$ $\mathrm{km})$ and our field surveys contributed 9 new mapping units $(40.9 \%$ of the total) (Figure 4). These results strongly supported our original hypothesis. As it stands now, the number of grid cells for the Saskatoon, occupied by prairie pasqueflower equals 22 , which accounts for $13.2 \%$ of total for the entire city.

During field surveys, we determined that some locations of prairie pasqueflower are no longer extant in Saskatoon over the last 50 years due to direct habitat destruction. It was found that densely built-up areas affect the survival of this species by reducing the extension of suitable habitat, fragmenting

\section{TABLE 2. List of phenological observations $(n=23)$ of prairie pasqueflower in Saskatchewan (SK PlantWatch database, 2001-2010).}

\begin{tabular}{|c|c|c|}
\hline LOCATION & ID & COORDINATES \\
\hline Turtle Lake Nature Sanctuary & PW1 & N53 36.422 W108 35.160 \\
\hline Tremblay & PW2 & N51 35.391 W103 00.599 \\
\hline Township Road 482 & PW3 & N53 10.998 W109 46.998 \\
\hline South of Hwy 10 & PW4 & N50 32.046 W104 06.589 \\
\hline Round Lake & PW5 & N53 21.131 W105 57.374 \\
\hline North side & PW6 & N53 30.955 W105 45.730 \\
\hline Nisbet North & PW7 & N53 12.890 W105 44.459 \\
\hline North-east Pinkerton & PW8 & N51 49.999 W102 28.998 \\
\hline North-east of Leader & PW9 & N50 53.993 W109 32.222 \\
\hline Lookout Point, Cypress Hills & PW10 & N49 35.019 W109 29.930 \\
\hline Hjertaas 1 & PW11 & N49 34.002 W101 42.000 \\
\hline Harvey Zieger 2 & PW12 & N51 36.000 W109 30.000 \\
\hline Harvey Zieger 1 & PW13 & N51 55.828 W109 51.412 \\
\hline Gardener Rd. W & PW14 & N53 12.433 W105 34.345 \\
\hline Flying Creek & PW15 & N50 12.772 W104 54.333 \\
\hline Farmyard & PW16 & N51 03.445 W103 06.470 \\
\hline Farmyard & PW17 & N50 20.286 W102 52.422 \\
\hline Farmyard & PW18 & N50 38.800 W103 49.183 \\
\hline Fairmount & PW19 & N51 25.002 W109 18.000 \\
\hline Fahlman Acres & PW20 & N53 12.276 W105 52.889 \\
\hline Daisy Meyers 1 & PW21 & N50 58.516 W109 59.230 \\
\hline Crocus Mountain & PW22 & N53 15.990 W109 59.230 \\
\hline Ray's Lake & PW23 & N53 32.685 W109 25.731 \\
\hline
\end{tabular}

\section{Conclusions}

The obtained results indicate that herbarium collections and phenological observations can be used as baseline data for mapping prairie pasqueflower. However, to obtain more detailed distribution data, specially designed target field surveys or predictive distribution modelling are required. High accuracy species distribution maps could be a powerful tool for population monitoring and effective conservation management.

\section{Acknowledgements}

List of people involved in gathering information from herbarium collections, phenology database and assisting with the field surveys, as well as numerous organizations supported this study was provided in our previous publication. ${ }^{1}$

1. Kricsfalusy V, Li M, Gupta C (2015) Using multiple data sources on species distribution for biodiversity assessment: the prairie crocus (Anemone patens) as a case study. Blue Jay 73(3): 102-122.

2. SASK - The W.P. Fraser Herbarium at the University of Saskatchewan (2011) http:// herbarium.usask.ca (Accessed: 23 May 2011).

3. USAS - The G.F. Ledingham Herbarium at the University of Regina (2011) http:// www.uregina.ca/science/biology/resources/ facilities/herbarium/index.html. (Accessed: October 8, 2013).

4. SK PlantWatch - Saskatchewan PlantWatch. Nature Saskatchewan (2011) http://www. naturesask.ca/?s=educationandp=saskatche wanplantwatch. (Accessed: June 27, 2011).

5. Kricsfalusy V, Miller G (2008) Invasion and distribution of Cynanchum rossicum (Asclepiadaceae) in the Toronto region, Canada, with remarks on its taxonomy. Thaiszia Journal of Botany 18: 21-36.

6. Esparrago J, Kricsfalusy V (2015) Traditional grassland management and surrounding land use drive the abundance of a prairie plant species in an urban landscape. Landscape and Urban Planning 142: 1-6.

7. Kricsfalusy V, Ponomarenko Y (2013) Notes on taxonomy, biology and ecology of the prairie crocus (Anemone patens L.) in Saskatchewan. Blue Jay 71(3): 135-148. 
TABLE 3. List of occurrences $(n=248)$ of prairie pasqueflower in Saskatchewan (author's field surveys, 2011-2018).

\begin{tabular}{|c|c|c|c|c|}
\hline LOCATION & ID & AUTHOR & DATE & COORDINATES \\
\hline Beaver Creek CA & BC1 & V. Kricsfalusy, Y. Ponomarenko & 11-May-11 & N51 58.814 W106 43.239 \\
\hline Beaver Creek CA & BC2 & V. Kricsfalusy, Y. Ponomarenko & 11-May-11 & N51 58.742 W106 43.094 \\
\hline Beaver Creek CA & $\mathrm{BC} 3$ & V. Kricsfalusy, Y. Ponomarenko & 11-May-11 & N51 58.715 W106 42.672 \\
\hline Beaver Creek CA & BC4 & V. Kricsfalusy, Y. Ponomarenko & 11-May-11 & N51 58.780 W106 42.693 \\
\hline Beaver Creek CA & BC5 & V. Kricsfalusy, Y. Ponomarenko & 11-May-11 & N51 58.747 W106 42.738 \\
\hline Beaver Creek CA & $\mathrm{BC6}$ & V. Kricsfalusy, Y. Ponomarenko & 11-May-11 & N51 58.963 W106 42.838 \\
\hline Beaver Creek CA & BC7 & V. Kricsfalusy, Y. Ponomarenko & 11-May-11 & N51 58.847 W106 42.406 \\
\hline Beaver Creek CA & $\mathrm{BC} 8$ & V. Kricsfalusy, Y. Ponomarenko & 11-May-11 & N51 58.806 W106 43.230 \\
\hline Beaver Creek CA & BC9 & V. Kricsfalusy, Y. Ponomarenko & 11-May-11 & N51 58.807 W106 42.639 \\
\hline Borden & BO1 & V. Kricsfalusy, R. Liu & 09-May-18 & N52 05.022 W107 10.614 \\
\hline Chief Whitecap Park & CWP1 & V. Kricsfalusy, Y. Ponomarenko & 19-May-11 & N52 03.508 W106 43.308 \\
\hline Cranberry Flats CA & CF1 & V. Kricsfalusy, Y. Ponomarenko & 09-May-11 & N52 01.974 W106 41.824 \\
\hline Cranberry Flats CA & CF2 & V. Kricsfalusy, Y. Ponomarenko & 09-May-11 & N52 01.997 W106 41.877 \\
\hline Cranberry Flats CA & CF3 & V. Kricsfalusy, Y. Ponomarenko & 09-May-11 & N52 02.005 W106 42.316 \\
\hline Cranberry Flats CA & CF4 & V. Kricsfalusy, Y. Ponomarenko & 09-May-11 & N52 02.024 W106 42.372 \\
\hline Cranberry Flats CA & CF5 & V. Kricsfalusy, Y. Ponomarenko & 09-May-11 & N52 02.078 W106 42.392 \\
\hline Cranberry Flats CA & CF6 & V. Kricsfalusy, Y. Ponomarenko & 09-May-11 & N52 02.060 W106 42.433 \\
\hline Cranberry Flats CA & CF7 & V. Kricsfalusy, Y. Ponomarenko & 09-May-11 & N52 02.001 W106 42.450 \\
\hline Cranberry Flats CA & CF8 & V. Kricsfalusy, Y. Ponomarenko & 19-May-11 & N52 01.857 W106 41.735 \\
\hline Cranberry Flats CA & CF9 & V. Kricsfalusy, Y. Ponomarenko & 29-Jun-11 & N52 01.935 W106 42.352 \\
\hline Cranberry Flats CA & CF10 & V. Kricsfalusy, Y. Ponomarenko & 29-Jun-11 & N52 01.930 W106 42.375 \\
\hline Cranberry Flats CA & CF11 & V. Kricsfalusy, Y. Ponomarenko & 29-Jun-11 & N52 02.006 W106 42.389 \\
\hline Cypress Hills IP & $\mathrm{CH} 1$ & V. Kricsfalusy, Y. Ponomarenko & 27-Jun-12 & N49 37.200 W109 56.400 \\
\hline Cypress Hills IP & $\mathrm{CH} 2$ & V. Kricsfalusy, Y. Ponomarenko & 27-Jun-12 & N49 37.800 W109 56.400 \\
\hline Cypress Hills IP & $\mathrm{CH} 4$ & V. Kricsfalusy, Y. Ponomarenko & 27-Jun-12 & N49 37.800 W109 55.800 \\
\hline Cypress Hills IP & $\mathrm{CH} 5$ & V. Kricsfalusy, Y. Ponomarenko & 28-Jun-12 & N49 39.000 W109 51.000 \\
\hline Cypress Hills IP & $\mathrm{CH} 6$ & V. Kricsfalusy, Y. Ponomarenko & 29-Jun-12 & N49 38.400 W109 31.200 \\
\hline Cypress Hills IP & $\mathrm{CH} 7$ & V. Kricsfalusy, Y. Ponomarenko & 27-Jun-12 & N49 39.000 W109 31.200 \\
\hline Cypress Hills IP & $\mathrm{CH} 8$ & V. Kricsfalusy, Y. Ponomarenko & 27-Jun-12 & N49 38.999 W109 31.188 \\
\hline Cypress Hills IP & $\mathrm{CH} 9$ & V. Kricsfalusy, Y. Ponomarenko & 27-Jun-12 & N49 40.800 W109 33.000 \\
\hline Prince Albert NP & PA1 & V. Kricsfalusy, Y. Ponomarenko & 15-Jun-12 & N53 52.024 W106 08.469 \\
\hline Prince Albert NP & PA2 & V. Kricsfalusy, Y. Ponomarenko & 15-Jun-12 & N53 13.416 W105 45.629 \\
\hline Prince Albert NP & PA3 & V. Kricsfalusy, Y. Ponomarenko & 15-Jun-12 & N53 36.135 W106 31.151 \\
\hline Redberry Lake BR & RBL1 & V. Kricsfalusy, Y. Ponomarenko & 23-Jun-11 & N52 40.203 W107 13.943 \\
\hline Redberry Lake BR & RBL2 & V. Kricsfalusy, Y. Ponomarenko & 23-Jun-11 & N52 40.218 W107 13.742 \\
\hline Redberry Lake BR & RBL3 & V. Kricsfalusy, Y. Ponomarenko & 23-Jun-11 & N52 43.282 W107 12.727 \\
\hline Redberry Lake BR & RBL4 & V. Kricsfalusy, Y. Ponomarenko & 23-Jun-11 & N52 42.456 W107 13.374 \\
\hline Redberry Lake BR & RBL5 & V. Kricsfalusy, Y. Ponomarenko & 19-Jul-11 & N52 50.547 W107 39.644 \\
\hline Redberry Lake BR & RBL6 & V. Kricsfalusy, Y. Ponomarenko & 19-Jul-11 & N52 50.458 W107 39.766 \\
\hline RM Redberry, Hawrysh Farm & HP1 & V. Kricsfalusy, Y. Ponomarenko & 23-Jun-11 & N52 36.249 W107 15.294 \\
\hline RM Redberry, Hawrysh Farm & HP2 & V. Kricsfalusy, Y. Ponomarenko & 24-Jun-11 & N52 36.197 W107 15.217 \\
\hline Saskatoon, Agra Road & AR1 & V. Kricsfalusy, Y. Ponomarenko & 05-May-12 & N52 10.294 W106 35.570 \\
\hline Saskatoon, Agra Road & AR2 & V. Kricsfalusy, Y. Ponomarenko & 05-May-12 & N52 10.239 W106 35.494 \\
\hline Saskatoon, Agra Road & AR3 & V. Kricsfalusy, Y. Ponomarenko & 05-May-12 & N52 10.180 W106 35.427 \\
\hline Saskatoon, Agra Road & AR4 & V. Kricsfalusy, Y. Ponomarenko & 05-May-12 & N52 10.158 W106 35.550 \\
\hline Saskatoon, Agra Road & AR5 & V. Kricsfalusy, Y. Ponomarenko & 05-May-12 & N52 10.321 W106 35.625 \\
\hline Saskatoon, Agra Road & AR6 & V. Kricsfalusy, Y. Ponomarenko & 05-May-12 & N52 10.368 W106 34.605 \\
\hline Saskatoon, Agra Road & AR7 & V. Kricsfalusy, Y. Ponomarenko & 05-May-12 & N52 10.354 W106 34.687 \\
\hline Saskatoon, Agra Road & AR8 & V. Kricsfalusy, Y. Ponomarenko & 05-May-12 & N52 10.366 W106 34.756 \\
\hline Saskatoon, Agra Road & AR9 & V. Kricsfalusy, Y. Ponomarenko & 05-May-12 & N52 10.336 W106 34.822 \\
\hline Saskatoon, Agra Road & AR10 & V. Kricsfalusy, Y. Ponomarenko & 05-May-12 & N52 10.298 W106 34.888 \\
\hline Saskatoon, Agra Road & AR11 & V. Kricsfalusy, Y. Ponomarenko & 05-May-12 & N52 10.231 W106 35.136 \\
\hline Saskatoon, Crocus Prairie & CP1 & V. Kricsfalusy, Y. Ponomarenko & 05-Jul-12 & N52 09.823 W106 36.365 \\
\hline Saskatoon, Crocus Prairie & CP2 & V. Kricsfalusy, Y. Ponomarenko & 05-Jul-12 & N52 09.934 W106 36.316 \\
\hline Saskatoon, Crocus Prairie & CP3 & V. Kricsfalusy, Y. Ponomarenko & 05-Jul-12 & N52 09.903 W106 36.257 \\
\hline Saskatoon, Kernen Prairie & KP1 & V. Kricsfalusy, Y. Ponomarenko & 13-May-11 & N52 09.593 W106 31.714 \\
\hline Saskatoon, Kernen Prairie & KP2 & V. Kricsfalusy, Y. Ponomarenko & 11-May-11 & N52 09.592 W106 31.824 \\
\hline Saskatoon, Kernen Prairie & KP3 & V. Kricsfalusy, Y. Ponomarenko & 11-May-11 & N52 09.549 W106 31.908 \\
\hline Saskatoon, Kernen Prairie & KP4 & V. Kricsfalusy, Y. Ponomarenko & 11-May-11 & N52 09.543 W106 31.993 \\
\hline Saskatoon, Kernen Prairie & KP5 & V. Kricsfalusy, Y. Ponomarenko & 11-May-11 & N52 09.582 W106 31.977 \\
\hline Saskatoon, Kernen Prairie & KP6 & V. Kricsfalusy, Y. Ponomarenko & 11-May-11 & N52 09.631 W106 31.998 \\
\hline Saskatoon, Kernen Prairie & KP7 & V. Kricsfalusy, Y. Ponomarenko & 11-May-11 & N52 09.673 W106 31.934 \\
\hline Saskatoon, Kernen Prairie & KP8 & V. Kricsfalusy, Y. Ponomarenko & 11-May-11 & N52 09.694 W106 31.812 \\
\hline Saskatoon, Kernen Prairie & KP9 & V. Kricsfalusy, Y. Ponomarenko & 11-May-11 & N52 09.665 W106 31.706 \\
\hline Saskatoon, Kernen Prairie & KP10 & V. Kricsfalusy, Y. Ponomarenko & 11-May-11 & N52 10.308 W106 31.964 \\
\hline Saskatoon, Kernen Prairie & KP11 & V. Kricsfalusy, Y. Ponomarenko & 11-May-11 & N52 10.214 W106 31.934 \\
\hline Saskatoon, Kernen Prairie & KP12 & V. Kricsfalusy, Y. Ponomarenko & 11-May-11 & N52 10.166 W106 31.933 \\
\hline Saskatoon, Kernen Prairie & KP13 & V. Kricsfalusy, Y. Ponomarenko & 11-May-11 & N52 10.099 W106 31.949 \\
\hline Saskatoon, Kernen Prairie & KP14 & V. Kricsfalusy, Y. Ponomarenko & 11-May-11 & N52 09.955 W106 31.812 \\
\hline Saskatoon, Kernen Prairie & KP15 & V. Kricsfalusy, Y. Ponomarenko & 11-May-11 & N52 09.890 W106 32.139 \\
\hline Saskatoon, Kernen Prairie & KP16 & V. Kricsfalusy, Y. Ponomarenko & 11-May-11 & N52 09.939 W106 32.184 \\
\hline Saskatoon, Kernen Prairie & KP17 & V. Kricsfalusy, Y. Ponomarenko & 11-May-11 & N52 10.040 W106 32.282 \\
\hline Saskatoon, Kernen Prairie & KP18 & V. Kricsfalusy, Y. Ponomarenko & 11-May-11 & N52 10.073 W106 32.217 \\
\hline Saskatoon, Kernen Prairie & KP19 & V. Kricsfalusy, Y. Ponomarenko & 11-May-11 & N52 10.120 W106 32.185 \\
\hline Saskatoon, Kernen Prairie & KP20 & V. Kricsfalusy, Y. Ponomarenko & 11-May-11 & N52 10.357 W106 32.052 \\
\hline Saskatoon, Kernen Prairie & KP21 & V. Kricsfalusy, Y. Ponomarenko & 11-May-11 & N52 10.352 W106 31.964 \\
\hline Saskatoon, Northeast Swale & NS1 & V. Kricsfalusy, Y. Ponomarenko & 25-May-11 & N52 10.335 W106 35.863 \\
\hline Saskatoon, Northeast Swale & NS2 & V. Kricsfalusy, Y. Ponomarenko & 25-May-11 & N52 10.257 W106 35.824 \\
\hline Saskatoon, Northeast Swale & NS3 & V. Kricsfalusy, Y. Ponomarenko & 25-May-11 & N52 10.255 W106 35.747 \\
\hline Saskatoon, Northeast Swale & NS4 & V. Kricsfalusy, Y. Ponomarenko & 25-May-11 & N52 10.314 W106 35.700 \\
\hline Saskatoon, Northeast Swale & NS5 & V. Kricsfalusy, Y. Ponomarenko & 25-May-11 & N52 10.355 W106 35.758 \\
\hline Saskatoon, Northeast Swale & NS6 & V. Kricsfalusy, Y. Ponomarenko & 25-May-11 & N52 10.430 W106 34.437 \\
\hline Saskatoon, Northeast Swale & NS7 & V. Kricsfalusy, Y. Ponomarenko & 25-May-11 & N52 10.477 W106 34.368 \\
\hline
\end{tabular}

\section{LOCATION}

Saskatoon, Northeast Swale

Saskatoon, Northeast Swale

Saskatoon, Northeast Swale

Saskatoon, Northeast Swale

Saskatoon, Northeast Swale

Saskatoon, Northeast Swale

Saskatoon, Northeast Swale

Saskatoon, Northeast Swale

Saskatoon, Northeast Swale

Saskatoon, Northeast Swale

Saskatoon, Northeast Swale

Saskatoon, Northeast Swale

Saskatoon, Northeast Swale

Saskatoon, Northeast Swale

Saskatoon, Northeast Swale

Saskatoon, Northeast Swale

Saskatoon, Northeast Swale

Saskatoon, Northeast Swale

Saskatoon, Northeast Swale

Saskatoon, Northeast Swale

Saskatoon, Northeast Swale

Saskatoon, Northeast Swale

Saskatoon, Northeast Swale

Saskatoon, Northeast Swale

Saskatoon, Northeast Swale

Saskatoon, Northeast Swale

Saskatoon, Northeast Swale

Saskatoon, Northeast Swale

Saskatoon, Northeast Swale

Saskatoon, Northeast Swale

Saskatoon, Northeast Swale

Saskatoon, Northeast Swale

Saskatoon, Northeast Swale

Saskatoon, Northeast Swale

Saskatoon, Northeast Swale

Saskatoon, Northeast Swale

Saskatoon, Peggy McKercher

Saskatoon, Peggy McKercher

Saskatoon, Peggy McKercher

Saskatoon, Peturrson's Ravine

Saskatoon, Peturrson's Ravine

Saskatoon, Peturrson's Ravine

Saskatoon, Range Road

Saskatoon, Range Road

Saskatoon, Range Road

Saskatoon, Range Road

Saskatoon, Range Road

Saskatoon Natural Grasslands

Saskatoon Natural Grasslands

Saskatoon Natural Grasslands

Saskatoon Natural Grasslands

Saskatoon Natural Grasslands

Saskatoon Natural Grasslands

Saskatoon Natural Grasslands

Saskatoon Natural Grasslands

Saskatoon Natural Grasslands

Saskatoon Natural Grasslands

Saskatoon Natural Grasslands

Saskatoon Natural Grasslands

Saskatoon Natural Grasslands

Saskatoon Natural Grasslands

Saskatoon Natural Grasslands

Saskatoon Natural Grasslands

Saskatoon, Small Swale

Saskatoon, Small Swale

Saskatoon, Small Swale

Saskatoon, Small Swale

Saskatoon, Small Swale

Saskatoon, Small Swale

Saskatoon, Small Swale

Saskatoon, Small Swale

Saskatoon, Small Swale

Saskatoon Small Swale

ID AUTHOR

\section{NS8}

NS9

NS12

NS13

NS14

NS15

NS17

NS18

NS19

NS20

NS21

NS22

NS24

NS25

NS28

NS30

NS3

NS34

NS35

NS36

NS37

NS38

NS34

NS4

NS42

NS44

NS46

NS47

NS48

NS550

MK1

MK2

MK3

PR2

PR3

PR5

RR1

RR2

RR3

RR

SNG

SNG

SNG3

SNG5

SNG6

SNG7

SNG8

SNG10

SNG11

SNG12

SNG 14

SNG15

SNG16

SNG17

SNG18

SNG1

SS1

SS3

SS4

SS5

S57

SS8

SS9

SS 10
V. Kricsfalusy,

V. Kricsfalusy,

V. Kricsfalusy,

V. Kricsfalusy,

V. Kricsfalusy,

V. Kricsfalusy,

V. Kricsfalusy,

V. Kricsfalusy,

V. Kricsfalusy,

,

V. Kricsfalusy,

V. Kricsfalusy,

V. Kricsfalusy,

V. Kricsfalusy,

Kricsfalusy,

V. Kricsfalusy,

, ricsfalusy,

V. Kricsfalusy,

V. Kricsfalusy,

Kricsfalusy,

V. Kricsfalusy,

Kricsfalusy,

V. Kricsfalusy,

Kricsfalusy,

V. Kricsfalusy,

V. Kricsfalusy,

V. Kricsfalusy,

V. Kricsfalusy,

V. Kricsfalusy,

icsfalusy,

V. Kricsfalusy,

V. Kricsfalusy,

. Kricsfalusy,

V. Kricsfalusy,

V. Kricsfalusy,

V. Kricsfalusy,

Kricsfalusy,

V. Kricsfalusy,

V. Kricsfalusy,

V. Kricsfalusy,

V. Kricsfalusy,

Kricsfalusy,

V. Kricsfalusy,

Kricsfalusy,

V. Kricsfalusy,

V. Kricsfalusy,

V. Kricsfalusy,

V. Kricsfalusy,

V. Kricsfalusy,

Kricsfalusy,

V. Kricsfalusy,

V. Kricsfalusy,

V. Kricsfalusy,

V. Kricsfalusy,

V. Kricsfalusy,

V. Kricsfalusy,

V. Kricsfalusy,

V. Kricsfalusy,

Kricsfalusy,

V. Kricsfalusy,

V. Kricsfalusy,

V. Kricsfalusy,

V. Kricsfalusy,

V. Kricsfalusy,

V. Kricsfalusy,

V. Kricsfalusy,

V. Kricsfalusy,

V. Kricsfalusy,
V. Kricsfalusy, 
\begin{tabular}{l|l|ll} 
Y. Ponomarenko & 25-May-11 & N52 10.498 W106 34.264
\end{tabular} Y. Ponomarenko $\quad$ 25-May-11 $\quad$ N52 10.528 W106 34.217 Y. Ponomarenko 25-May-11 N52 10.572 W106 34.186 Y. Ponomarenko $\quad$ 25-May-11 N52 10.768 W106 34.032 Y. Ponomarenko $\quad$ 25-May-11 N52 10.827 W106 34.077 Y. Ponomarenko 25-May-11 N52 10.812 W106 33.906 Y. Ponomarenko $\quad$ 25-May-11 $\quad$ N52 10.601 W106 33.852 Y. Ponomarenko $\quad$ 25-May-11 $\quad$ N52 10.568 W106 33.987 Y. Ponomarenko $\quad$ 25-May-11 N52 10.458 W106 34.285 Y. Ponomarenko 25-May-11 N52 10.823 W106 33.463 Y. Ponomarenko $\quad$ 25-May-11 $\quad$ N52 10.800 W106 33.580 Y. Ponomarenko $25-$ May-11 $\quad$ N52 10.759 W106 33.627 Y. Ponomarenko 25-May-11 N52 10.821 W106 33.633 Y. Ponomarenko $\quad$ 25-May-11 N52 10.819 W106 33.718 \begin{tabular}{l|l|l} 
Y. Ponomarenko & 25-May-11 & N52 10.834 W106 33.781
\end{tabular} Y. Ponomarenko 25-May-11 N52 10.931 W106 33.824 Y. Ponomarenko $\quad$ 25-May-11 N52 11.036 W106 33.834 Y. Ponomarenko 25-May-11 N52 11.049 W106 33.696 Y. Ponomarenko $\quad$ 25-May-11 $\quad$ N52 11.117 W106 33.660 Y. Ponomarenko Y. Ponomarenko Y. Ponomarenko Y. Ponomarenko

Y. Ponomarenko

Y. Ponomarenko

Y. Ponomarenko

Y. Ponomarenko

Y. Ponomarenko

Y. Ponomarenko

Y. Ponomarenko

Y. Ponomarenko

Y. Ponomarenko

Y. Ponomarenko

Y. Ponomarenko

Y. Ponomarenko

Y. Ponomarenko

Y. Ponomarenko

Y. Ponomarenko

J. Esparrago

J. Esparrago

J. Esparrago

J. Esparrago

J. Esparrago

J. Esparrago

J. Esparrago

J. Esparrago

Y. Ponomarenko

Y. Ponomarenko

Y. Ponomarenko

Y. Ponomarenko

Y. Ponomarenko

Y. Ponomarenko

Y. Ponomarenko

Y. Ponomarenko

Y. Ponomarenko

Y. Ponomarenko

Y. Ponomarenko

Y. Ponomarenko

Y. Ponomarenko

Y. Ponomarenko

Y. Ponomarenko

Y. Ponomarenko

Y. Ponomarenko

Y. Ponomarenko

Y. Ponor

S. Zhao

S. Zhao

S. Zhao

S. Zhao

S. Zhao

S. Zhao

S. Zhao

S. Zhao

S. Zhao

S. Zhao

25-May-11 N52 11.291 W106 33.508

07-Jul-11 N52 11.440 W106 33.349

07-Jul-11 N52 10.625 W106 34.059

07-Jul-11 N52 10.799 W106 34.078

N52 10.841 W106 33.850

N52 10.826 W106 34.464

N52 10.810 W106 34.382

15-May-12 N52 10.853 W106 34.346

15-May-12 N52 10.895 W106 34.279

15-May-12 N52 10.955 W106 34.170

15-May-12 N52 10.994 W106 34.131

5-May-12 N52 10.988 W106 33.984

15-May-12 N52 11.106 W106 33.940

15-May-12 N52 11.213 W106 33.840

15-May-12 N52 11.152 W106 33.813

15-May-12 N52 10.980 W106 33.931

15-May-12 N52 10.955 W106 33.956

15-May-12 N52 10.907 W106 33.972

15-May-12 N52 10.925 W106 34.082

N5-May-12 N2 10.869 W106 34.158

15-May-12 N52 10.937 W106 34.248

17-May-11 N52 11.099 W106 36.014

17-May-11 N52 11.001 W106 35.955

17-May-11 N52 10.947 W106 35.951

15-May-11 N52 10.013 W106 36.355

15-May-11 N52 09.995 W106 36.357

15-May-11 N52 10.199 W106 36.194

5-May-11 N52 10.081 W106 36.032

15-May-11 N52 10.113 W106 35.986

N52 12.294 W106 35.829

05-May-12 N52 12.151 W106 35.915

05-May-12 N52 11.939 W106 35.741

05-May-12 N52 11.620 W106 35.790

05-May-12 N52 10.898 W106 35.816

14-May-11 N52 09.697 W106 35.439

4-May-11 N52 09.763 W106 35.450

14-May-11 N52 09.741 W106 35.494

14-May-11 N52 09.783 W106 35.502

14-May-11 N52 09.807 W106 35.538

14-May-11 N52 09.839 W106 35.561

14-May-11 N52 09.858 W106 35.620

14-May-11 N52 09.883 W106 35.595

14-May-11 N52 09.835 W106 35.420

14-May-11 N52 09.806 W106 35.421

14-May-11 N52 09.854 W106 35.294

14-May-11 N52 09.927 W106 35.669

14-May-11 N52 09.972 W106 35.629

14-May-11 N52 10.017 W106 35.630

14-May-11 N52 09.927 W106 35.864

14-May-11 N52 09.877 W106 35.859

14-May-11 N52 09.966 W106 35.622

14-May-11 N52 09.774 W106 35.488

06-Jun-13 N52 11.134 W106 35.841

06-Jun-13 N52 11.351 W106 35.438

06-Jun-13 N52 11.486 W106 35.270

06-Jun-13 N52 11.524 W106 35.049

06-Jun-13 N52 11.501 W106 35.003

06-Jun-13 N52 11.689 W106 35.075

06-Jun-13 N52 11.645 W106 34.919

06-Jun-13 N52 11.667 W106 34.880

06-Jun-13 N52 11.706 W106 34.859

06-Jun-13 N52 11.753 W106 34.824
Saskatoon, Small Swale

Saskatoon, Small Swale

Saskatoon, Small Swale

Saskatoon, Small Swale

Saskatoon, Small Swale

Saskatoon, Small Swale

Saskatoon, Small Swale

Saskatoon, Small Swale

Saskatoon, Small Swale

Saskatoon, Small Swale

Saskatoon, Small Swale

Saskatoon

Saskatoon

Saskatoon

Saskatoon

Saskatoon

Saskatoon

Saskatoon

Saskatoon

Saskatoon

Saskatoon

Saskatoon

Saskatoon

Saskatoon

Saskatoon

Saskatoon

Saskatoon

Saskatoon

Saskatoon

Saskatoon

Saskatoon

Saskatoon

Saskatoon

Saskatoon

Saskatoon

Saskatoon

Saskatoon

Saskatoon

Saskatoon

Saskatoon

Saskatoon

Saskatoon

Saskatoon

Saskatoon

Saskatoon

Wanuskewin Heritage Park

Wanuskewin Heritage Park

Wanuskewin Heritage Park

Wanuskewin Heritage Park

Wanuskewin Heritage Park

Wanuskewin Heritage Park

Wanuskewin Heritage Park

Wanuskewin Heritage Park

Wanuskewin Heritage Park

Wanuskewin Heritage Park

Wanuskewin Heritage Park

Wanuskewin Heritage Park

Wanuskewin Heritage Park

Wanuskewin Heritage Park

Wanuskewin Heritage Park

Wanuskewin Heritage Park

Wanuskewin Heritage Park

Wanuskewin Heritage Park

Wanuskewin Heritage Park

Wanuskewin Heritage Park

Wanuskewin Heritage Park

Wanuskewin Heritage Park

Wanuskewin Heritage Park

Wanuskewin Heritage Park

Wanuskewin Heritage Park

Wanuskewin Heritage Park

Wanuskewin Heritage Park

Wanuskewin Heritage Park

Wanuskewin Heritage Park

Wanuskewin Heritage Park

\begin{tabular}{|l|l} 
SS11 & V. Kricsfalusy, S. Zhao \\
\hline
\end{tabular}

SS12 V. Kricsfalusy, S. Zhao

SS13 V. Kricsfalusy, S. Zhao

SS14 V. Kricsfalusy, S. Zhao

SS15 V. Kricsfalusy, S. Zhao

V. Kricsfalusy, S. Zhao

SS17 V. Kricsfalusy, S. Zhao

SS18 V. Kricsfalusy, S. Zhao

SS19 V. Kricsfalusy, S. Zhao

SS20 V. Kricsfalusy, S. Zhao

SS21 V. Kricsfalusy, S. Zhao

V. Kricsfalusy, J. Esparrago

ST2 V. Kricsfalusy, J. Esparrago

V. Kricsfalusy, J. Esparrago

\begin{tabular}{l|l} 
ST5 & V. Kricsfalusy, J. Esparrago
\end{tabular}

ST6 V. Kricsfalusy, J. Esparrago

ST7 V. Kricsfalusy, J. Esparrago

\begin{tabular}{l|l} 
ST8 & V. Kricsfalusy, J. Esparrago
\end{tabular}

ST9

V. Kricsfalusy, J. Esparrago

V. Kricsfalusy, J. Esparrago

V. Kricsfalusy, J. Esparrago

V. Kricsfalusy, J. Esparrago

V. Kricsfalusy, J. Esparrago

V. Kricsfalusy, J. Esparrago

V. Kricsfalusy, J. Esparrago

V. Kricsfalusy, J. Esparrago

V. Kricsfalusy, J. Esparrago

V. Kricsfalusy, J. Esparrago

V. Kricsfalusy, J. Esparrago

V. Kricsfalusy, J. Esparrago

V. Kricsfalusy, J. Esparrago

V. Kricsfalusy, J. Esparrago

V. Kricsfalusy, J. Esparrago

V. Kricsfalusy, J. Esparrago

V. Kricsfalusy, J. Esparrago

V. Kricsfalusy, J. Esparrago

V. Kricsfalusy, J. Esparrago

V. Kricsfalusy, J. Esparrago

V. Kricsfalusy, J. Esparrago

V. Kricsfalusy, J. Esparrago

V. Kricsfalusy, J. Esparrago

V. Kricsfalusy, J. Esparrago

V. Kricsfalusy, J. Esparrago

V. Kricsfalusy, J. Esparrago

V. Kricsfalusy, J. Esparrago

V. Kricsfalusy, J. Esparrago

V. Kricsfalusy, J. Esparrago

V. Kricsfalusy, J. Esparrago

V. Kricsfalusy, J. Esparrago

V. Kricsfalusy, J. Esparrago

V. Kricsfalusy, J. Esparrago

V. Kricsfalusy, J. Esparrago

V. Kricsfalusy, J. Esparrago

V. Kricsfalusy, J. Esparrago

V. Kricsfalusy, J. Esparrago

V. Kricsfalusy, J. Esparrago

V. Kricsfalusy, J. Esparrago

V. Kricsfalusy, J. Esparrago

WHP8 V. Kricsfalusy, J. Esparrago

WHP9 V. Kricsfalusy, J. Esparrago

WHP10 V. Kricsfalusy, J. Esparrago

WHP11 V. Kricsfalusy, J. Esparrago

WHP12 V. Kricsfalusy, J. Esparrago

WHP13 V. Kricsfalusy, J. Esparrago

WHP14 V. Kricsfalusy, J. Esparrago

WHP15 V. Kricsfalusy, J. Esparrago

WHP16 V. Kricsfalusy, J. Esparrago

WHP17

V. Kricsfalusy, J. Esparrago 